\title{
Aerococcus urinae: An under-recognized cause of UTI
}

\author{
Schempf T BS ${ }^{1 *}$, Beg H MD ${ }^{1}$, Tenner C MD ${ }^{1,2}$
}

Schempf TBS, Beg HMD, Tenner CMD. Aerococcus urinae: An under-recognized cause of UTI in internal medicine. Curr Res Integr Med 2018;3(S1):1112.

W e present a case of an 84-year-old man with a history of advanced Alzheimer's disease who was brought in after an episode of syncope in the setting of having a bowel movement. Evaluation was remarkable only for a positive urinalysis and a urine culture that ultimately grew $>100,000 \mathrm{CFU} / \mathrm{mL}$ pan-sensitive Aerococcus urinae species. The patient was discharged on oral cefpodoxime with a diagnosis of vasovagal syncope and a urinary tract infection related to a relatively under-recognized organism.

Aerococci urinae is a Gram-positive, catalase-negative, bacterium that grows in clusters, often appearing in colonies that resemble Streptococci viridans (1). Its genus was first described in 1953, with the first reported case of A. urinae in a human described in $1992(1,2)$. Several other species in the Aerococcus genus have been identified, including the pathogenic A. sanguinicola and the less-pathogenic A. christensenii and A. urinaehominus (3-5). While rarely recognized in the past, A. urinae has become more commonly isolated in bacterial cultures, as bacterial detection has improved (6). It has noted to be often confused with several other bacterial genii, including Streptococci, Staphylococci, and Enterococci (7). In fact, one study showed that in a series of 820 isolates thought to be Streptococci species, 1\% was found to be Aerococcus species on further evaluation (8). Preliminary studies by Rasmussen et al. showed that the true incidence of Aerococci infections could be seven times that than previously described (7). Genomic sequencing and mass spectrometry are the most sensitive modalities for detection of $A$. urinae, although many lower-resource clinical settings may not have access to this technology (9)

The organism has been implicated most commonly as a cause of urinary tract infection but cases of endocarditis and sepsis have been reported $(6,10,11)$. The incidence of Aerococci species isolated from urinary cultures is generally believed to range from $0.2 \%-0.8 \%$; of these patients, it is unclear the proportion of which present symptomatically, with reported figures ranging from $50 \%-100 \%(12-16)$. Of urine cultures positive for Aerococcus species, A. urinae was shown to represent $55 \%-65 \%(14,16,17)$. As with most UTIs, A. urinae is seen more commonly in elderly patients (12-16). One study showed that $67.5 \%$ of infected patients had underlying systemic diseases, most commonly diabetes mellitus, malignancy, and dementia (18). Notably, several other types of infection due to A. urinae, as well as other Aerococcus species, have been described, including peritonitis, osteomyelitis, dental, joint, and soft-tissue infections $(6,19-26)$. While these cases are less common than UTI and endocarditis due to A. urinae, providers need to be aware of this pathogenic organism.

A. urinae is a pathogen that is much more common than previously described. Fortunately, it is generally sensitive to a number of antibiotics including beta-lactams, cephaloporins and carbapenems (27). Rasmussen suggests ampicillin as a drug option of choice for sepsis from a urinary source, noting that cephalosporins and carbapenems are unnecessarily broad spectrum (7). Unfortunately, there has been little investigation of treatment options in clinical trials, but in vitro studies have offered insight into treatment options for patients with A. urinae infections. Our patient exhibited a typical presentation for A. urinae infection, and in an ever-growing elderly population, knowledge and recognition of this potential pathogen is of increasing importance.

\section{REFERENCES}

1. Williams REO, Hirch A, Cowan ST. Aerococcus, a New Bacterial Genus. Microbiol. 1953;8(3):475-80.

2. Aguirre M, Collins MD. Phylogenetic analysis of some Aerococcus-like organisms from urinary tract infections: Description of Aerococcus urinae sp. nov. J Gen Microbiol. 1992;138(2):401-5.

3. Lawson PA, Falsen E, Ohlen M, et al. Aerococcus urinaehominis sp. nov., isolated from human urine. Int J Syst Evol Microbiol. 2001;51(Pt 2):683-6

4. Collins MD, Jovita MR, Hutson RA, et al. Aerococcus christensenii sp. nov., from the human vagina. Int J Syst Bacteriol. 1999;49 (Pt 3):1125-8.

5. Lawson PA, Falsen E, Truberg-Jensen K, et al. Aerococcus sanguicola sp. nov., isolated from a human clinical source. Int J Syst Evol Microbiol. 2001;51:475-9

6. Senneby E, Petersson AC, Rasmussen M. Clinical and microbiological features of bacteraemia with Aerococcus urinae. Clin Microbiol Infect. 2012;18(6):546-50

7. Rasmussen M. Aerococcus: An increasingly acknowledged human pathogen. Clin Microbiol Infect. 2016;22(1):22-7.

8. Parker MT, Ball LC. Streptococci and aerococci associated with systemic infection in man. J Med Microbiol. 1976;9(3):275-302.

9. Christensen JJ, Dargis R, Hammer M, et al. Matrix-assisted laser desorption ionization-time of flight mass spectrometry analysis of Grampositive, catalase-negative cocci not belonging to the Streptococcus or Enterococcus genus and benefits of database extension. J Clin Microbiol. 2012;50(5):1787-91.

10. Christensen JJ, Jensen IP, Faerk J. Bacteremia/septicemia due to Aerococcus-like organisms: Report of seventeen cases. Danish ALO Study Group. Clin Infect Dis. 1995;21(4):943-7.

11. de Jong MF, Soetekouw R, ten Kate RW, et al. Aerococcus urinae: Severe and fatal bloodstream infections and endocarditis. J Clin Microbiol. 2010;48(9):3445-7.

12. Christensen JJ, Korner B, Kjaergaard H. Aerococcus-like organism-an unnoticed urinary tract pathogen. APMIS. 1989;97(6):539-46.

13. Schuur PM, Kasteren ME, Sabbe L, et al. Urinary tract infections with Aerococcus urinae in the south of The Netherlands. Eur J Clin Microbiol Infect Dis. 1997;16(12):871-5.

14. Cattoir V, Kobal A, Legrand P. Aerococcus urinae and Aerococcus sanguinicola, two frequently misidentified uropathogens. Scand J Infect Dis. 2010;42(10):775-80.

${ }^{1}$ New York University Langone Medical Center, USA; ${ }^{2}$ Veteran Affairs New York Harbor Healthcare System, USA

*Correspondence: K Tadhg Schempf, BS, New York University Langone Medical Center, New York, USA, Telephone 4123105003, e-mail Tadhg.Schempf@med.nyu.edu

Received: July 09, 2018, Accepted: July 18, 2018, Published: July 30, 2018

open Access

This open-access article is distributed under the terms of the Creative Commons Attribution Non-Commercial License (CC BY-NC) (http:// creativecommons.org/licenses/by-nc/4.0/), which permits reuse, distribution and reproduction of the article, provided that the original work is properly cited and the reuse is restricted to noncommercial purposes. For commercial reuse, contact reprints@pulsus.com 
15. Sierra-Hoffman M, Watkins K, Jinadatha $C$, et al. Clinical significance of Aerococcus urinae: A retrospective review. Diagn Microbiol Infect Dis. 2005;53(4):289-92.

16. Shelton-Dodge K, Vetter EA, Kohner PC, et al. Clinical significance and antimicrobial susceptibilities of Aerococcus sanguinicola and Aerococcus urinae. Diagn Microbiol Infect Dis. 2011;70(4):448-51.

17. Senneby E, Petersson AC, Rasmussen M. Epidemiology and antibiotic susceptibility of aerococci in urinary cultures. Diagn Microbiol Infect Dis. 2015;81(2): 149-51.

18. Schuur PM, Kasteren ME, Sabbe L, et al. Urinary tract infections with Aerococcus urinae in the south of The Netherlands. Eur J Clin Microbiol Infect Dis. 1997;16(12):871-5.

19. Naghibi M, Javaid MM, Holt SG. Case study: Aerococcus urinae as pathogen in peritoneal dialysis peritonitis a first report. Perit Dial Int. 2007;27(6):715-6.

20. Colakoglu S, Turunc T, Taskoparan M, et al. Three cases of serious infection caused by Aerococcus urinae: A patient with spontaneous bacterial peritonitis and two patients with bacteremia. Infection. 2008;36(3):288-90
21. Astudillo L, Sailler L, Porte L, et al. Spondylodiscitis due to Aerococcus urinae: A First Report. Scand J Infect Dis. 2003;35(11-12):891-2.

22. Santos R, Santos E, Gonçalves S, et al. Lymphadenitis caused by Aerococcus urinae Infection. Scand J Infect Dis. 2003;35(5):353-4.

23. Schuur PM, Sabbe L, van der Wouw AJ, et al. Three cases of serious infection caused by Aerococcus urinae. Eur J Clin Microbiol Infect Dis. 1999;18(5):368-71.

24. Jost C, Breton B, Biran V, et al. First case of pregnant women bacteraemia and probable early-onset neonatal infection due to Aerococcus urinae. New Microbes and New Infect. 2015;3:1-3.

25. Jiang X, Yang S, Sun G. Odontogenic Infection Due to Aerococcus viridans: A Case Report. J Oral Maxillofac Surg. 2013;71(9):1552-4.

26. Goetz LL, Powell DJ, Castillo TA, et al. Hip abscess due to Aerococcus urinae in a man with paraplegia: Case report. Spinal cord. 2013;51(12):929-30.

27. Humphries RM, Hindler JA. In vitro antimicrobial susceptibility of Aerococcus urinae. J Clin Microbiol. 2014;52(6):2177-80. 